\title{
PARTURIENT AND METABOLIC DISTURBANCES IN THE COW AND THEIR INFLUENCE UPON MILK PRODUCTION
}

\author{
AARNE MÄKELÄ \\ Department of Animal Husbandry, University of Helsinki
}

Received October 24, 1963

There are many disturbances which can occur in connection with calving of the cow, for instance, retention of afterbirth, difficult calving, twinning, birth of a dead calf, and abortion. In addition, certain metabolic disturbances, such as parturient paresis, grass tetany, and ketosis, usually occur shortly after calving. Many reports have been made in the literature concerning the occurrence of such disturbances, but only little attention has been paid to their influence upon milk production.

Retention of the afterbirth is a common condition. If its treatment is left neglected, milk production decreases (1, p. 310; 4, p. 383; 9, p. 115).

According to Vainikainen (23, p. 5), twin births comprise about $2 \%$ of the total births in the Ayrshire breed and in Finnish LSK cattle in Finland. Roemer et al. (18, p. 149) found twin births to make up $2 \%$ and MEADows and Lush (12, p. 1430) $2.9 \%$ of the total births in their respective studies. Among the Ayrshire cows investigated by Vainikainen (23, p. 5), $19 \%$ of the cows giving birth to twins also produced twins a second time. According to Vainikainen (23, p. 8), the milk and milk fat productions as well as the milk fat percentage were slightly lower in the lactation following the birth of twins than in the preceeding and subsequent lactations in which the cow had only one calf. In the study of Meadows and Lush $(12$, p. 1430) the butterfat production during the lactation following the birth of twins was $21.0 \pm 11.0 \mathrm{lb}$. lower than in the lactation immediately predeeding this birth.

Abortion may be caused either by the disease contagious abortion or by some mechanical fault, although, according to ECKLES (5, p. 405) the latter condition is infrequent. According to Roemer et al. (18, p. 147), hereditary constitutional weakness may also be a cause of abortion. These investigators found that abortion reduced the milk production in the immediate and the following lactations by $12-14 \%$ on the average. 
Parturient paresis (milk fever) occurs most frequently in older, high-producing cows $(22$, p. 89$)$. According to an extensive study made in Sweden by Jönsson $(10$, p. 11), parturient paresis did not occur at all in first-time parturitions ,whereas its frequency among the second parturitions was only $0.5 \%$ and among the sixth parturitions $13.9 \%$. Milk fever generally occurs within two days after calving which is usually normal and easy $(5$, p. $413 ; 24$, p. 401$)$. The length of the dry period apparently does not affect the incidence of this disease. On the other hand, the parturition interval is longer before parturitions with paresis than before normal ones $(10$, p. 35$)$. According to Shaw $(22$, p. 89$)$ the season of the year has probably no influence on the incidence of milk fever. In the investigation of Jönsson (10, p. 23), on the contrary, parturient paresis occurred more frequently during the pasture season than during the indoor period. Cows which have suffered once from this disease are more susceptible to it at subsequent parturitions $(22$, p. 89 ; 10 , p. 21). Such an affected cow ceases to eat, and as a result its milk production decreases rapidly (24, p. 401). According to GARNER (7, p. 123) parturient paresis causes large losses in milk production as a result of the decline in yield at the beginning phase of lactation.

The frequency of parturient paresis can be reduced by prophylactic measures. The risk of this disease can be diminished to a certain extent by delaying the first milking after parturition and by making it incomplete, or by allowing the calf to suckle during the first days after parturition (10, p. 39). The use of vitamin D has also proved to be effective in preventing milk fever. HibBs and Pounden (8) recommend the feeding of 30 million international units per day for at least 3 days and preferably not more than 7 days prepartum and one day postpartum. Jönsson (11) recommends the oral administration of 20 million I.U. daily for $2-5$ days before and $1-2$ days after parturition. Vitamin D can also be given intramuscularly. In this case, use can be made of the method of Paloheimo, described later in this paper, or that of Mizrachi (13), in which 20 million units are given in 4 doses at $2-3$ day intervals, with the final dose 2 days before calving. According to ENDER et al. (6, p. 32), cows which previously were afflicted with parturient paresis can be protected against subsequent attacks by prepartal feeding with fodder of normal alkali alkalinity but which is high in phosphorus and low in calcium.

Grass tetany occurs most frequently in high-producing and older cows during the early part of their lactation, especially in the spring when the cattle are let out to pasture (22, p. 89). According to BECKER (2) hereditary factors have an influence on the occurrence of grass tetany. This disease occurs not only in lactating cows, but also in heifers, beef cattle and bulls (20, p. 30$)$.

Prophylactic measures can also reduce the frequency if grass tetany. According to Westermarck $(24$, p. 403) the change from indoor feeding to pasture feeding must take place gradually. It is also important to avoid heavy manuring of the pasture with dung or with nitrogen and potash fertilizers. Rook and STORRY $(19$, p. 1069) found that the risk of severe hypomagnesaemia and tetany is increased by heavy dressings of nitrogen (especially in the form of $\mathrm{NH}_{4}$ salts), heavy potash applications, as well as a high $\mathrm{K}$ and low $\mathrm{Na}$ content and a high 
$\mathrm{K}:(\mathrm{Ca}+\mathrm{Mg})$ ratio in the pasture grass. According to these research workers, hypomagnesaemia does not occur when the pasture herbage contains more than $0.2 \mathrm{~g} \mathrm{Mg}$ per $100 \mathrm{~g}$ dry matter. They recommend a daily dose of $50 \mathrm{~g} \mathrm{MgO}$ per head of cattle to be given in liquid form throughout the period of risk. An alternative method is the application of $20-50 \mathrm{~kg} \mathrm{MgO}$ per hectare a few days before the beginning of grazing. SAARINEN (20, p. 31) has reviewed the literature and made a summary of the prophylactic measures against grass tetany, which are as follows: 1) the avoidance of digestive disturbances, 2) sufficient digestible fibre in the rations, especially in connection with heavy protein feeding, and 3) abundant dosages of common salt, magnesium and copper during the period of risk.

Ketosis (acetonaemia) usually occurs in high-producing cows which are in excellent condition ( 5 , p. $418 ; 22$, p. 102). The symptoms of this disease usually begin $2-3$ weeks after calving but can vary from one week to $2-3$ months (17, p. 54). Ketosis is most prevalent in cows after the third to sixth parturitions and especially during the winter feeding period (22, p. 102). The fact that many cows develop ketosis year after year suggests that genetic factors may render these animals less resistant to the disease (21, p. 404). Cows that suffer from milk fever are often liable also to acetonaemia, both disturbances occurring after the same parturition (22, p. 102). The most typical symptom of ketosis is loss of appetite, which results in a loss of weight and a rapid decline in milk production (5, p. 418; 20 , p. 8). The daily milk yield may decrease from $20-25 \mathrm{~kg}$ to only $5-10 \mathrm{~kg}$. Even though the condition may improve without special treatment, the loss in milk production is nevertheless great (17, p. 54). According to Shaw (21, p. 404) the milk yield may decline by more than $50 \%$ and the loss in body weight may be as much as $100 \mathrm{~kg}$ within one month.

\section{Experimental}

The experimental material in this study has been collected from the bookkeeping records of the cattle at the University Farm Viik. The cattle are of the Ayrshire breed and the herd consists of about 70 cows. Since the year 1947 daily milk weighings have been made of cows at the ascending phase of lactation until their peak production has definitely been passed. Two papers have previously been published on this material $(14,15)$, the first treating the designing of the average lactation curve at the ascending phase and the second the factors affecting the lactation curve at the ascending phase. In the latter paper only healthy cows were considered.

The present paper deals with the occurrence of parturient and metabolic disturbances in cattle and their influence upon milk production, especially at the ascending phase. The following parturient disturbances are considered: retention of afterbirth (retained placenta), difficult calving, twinning, birth of a dead calf, and abortion. The metabolic disturbances investigated are the following: parturient paresis, grass tetany, and ketosis (acetonaemia). Between the year 1947 and the end of the control year 1961-62 about 900 calvings occurred among the cattle under investigation. The average milk production during most of the time has been 
about $4000 \mathrm{~kg}$ per head per control year; in recent years, the figure has risen to around $5000 \mathrm{~kg}$.

In evaluating the influence of parturient and metabolic disturbances upon milk production, endeavours have been made to estimate how much the disturbance has changed the shape of the lactation curve at the ascending phase and how much it has lowered the peak.

In estimating the influence of the disturbance upon the shape of the lactation curve, Table 1 has been used. The percentage figures in this table indicate the production during the beginning of lactation expressed as percentages of the peak and divided into three groups: most frequent yield level, as well as yield levels when the disturbance affects moderately and severely. In determining the most frequent percentages, the average lactation curves at the ascending phase of healthy cows have been used (15). The disturbance was considered to have affected moderately if the yield level was $10-20 \%$-units lower than that of healthy cows $(=$ most frequent production), and a severe effect was considered when the yield level was more than $20 \%$-units lover than that of healthy cows. The determination of these percentage figures was partly based on the fact that the standard deviation of the average milk production in the first three days after calving was about $7 \%$ from the peak in heifer cows and about $8 \%$ in cows older than heifers, presuming that the average productions were calculated in percentages from the peak (15, p. 182). The times during the ascending phase have been calculated from the day of calving, which is considered as the 0-day. The duration of the ascending phase is the interval between calving and the peak. During the eardy part of the ascending phase the percentages are given separately for heifer cows and older cows. Two days from calving denotes the average of the first three days.

Table 1. Evaluation of the shape of the lactation curve at the ascending phase.

Time during
lactation

2 days

from calving

$1 / 8$ of the

ascending phase

$1 / 4$ of the

ascending phase

$1 / 2$ of the

ascending phase

\section{Type \\ of cows}

Heifer cows
Older cows
Heifer cows
Older cows

All cows

All cows

Most
frequent
$45-55 \%$
$55-65 \%$
$60-70 \%$
$65-75 \%$
$75-85 \%$
$80-90 \%$

Daily milk yield, \% of the peak
Severe

disturbance
$<30 \%$

$<40 \%$

$<45 \%$

$<50 \%$

$<60 \%$

$<65 \%$

An evaluation of moderate influence of the disturbance corresponds usually to a drop in daily milk yield of $2-4 \mathrm{~kg}$ in heifer cows and $3-5 \mathrm{~kg}$ in older cows. When the influence was evaluated as severe, the decrease in daily milk yield was generally greater than $4 \mathrm{~kg}$ in heifer cows and more than $5 \mathrm{~kg}$ in older cows.

The influence of the disturbance on the peak production was estimated by comparing the lactation peak when the cow suffered from the disturbance with the peaks of the same cow during normal lactations. Since the lactation peaks of even 
the same cow vary considerably from year to year, only large influences due to the disturbances could be observed.

In connection with some of the disturbances investigated, the duration of the gestation period was examined in order to determine whether it was normal or not. The average duration of gestation in the Ayrshire cattle at the University Farm Viik (16, p. 80 ) has been 280 days with a standard deviation of 4.3 days in those cases when one living calf was born. In cases of twinning the gestation period was on an average of 7 days shorter. If one calf was born after a gestation period of less than 270 days, the case was considered as an abortion.

Among the metabolic disturbances, the influence of parturient paresis was evaluated according to the same principle as that used in the case of parturient disturbances; this presumed that the paresis occurred on the day of calving or on the following day (which happened in about $3 / 4$ of the cases). The shape of the lactation curve and the peak production were investigated only in those cows which were unaffected by other diseases during the ascending phase.

In the case of the metabolic disturbances, endeavours were also made to estimate to what extent the disease reduced the milk production of the lactation period. This was done by comparing the production during the lactation when the cow was afflicted by the disturbance to the nearest normal production of the lactation period in which the same cow was healthy. This comparison was made only in those cases when no other disturbances besides grass tetany or ketosis had occurred. Often no suitable normal lactation period for the comparison was available. The production of the lactation period was estimated for a duration of 12 months in order to reduce the effect of the calving interval.

The influence of metabolic disturbances on the milk production during the ascending phase has also been determined graphically. In these instances lactation curves have been drawn, in which both the production values and the times are averages. When average lactation curves are shown, they have been designed so that both the productions and the durations of the ascending phase, as well as the fixed fractions of these durations $(1 / 8,1 / 4,1 / 2,3 / 4$ and $5 / 4$ of the total period after calving) are average values. A complete description of the method of designing such lactation curves has been presented in an earlier paper (14).

The influence of different factors on the frequency of the disease concerned has been examined by using the $\chi^{2}$-test according to the method of BonNIER and TEDIN (3, p. 195). In using this test, the distribution of the disease has been compared with the distribution of the calvings. The repeatability of certain diseases has been studied by using analysis of variance with one dimension, in which case the value corresponding to the occurrence of the disease $=1$ and the value otherwise $=0$. The test has been performed according to Bonnier and Tedin (3, p. 34).

\section{The occurrence of parturient disturbances and their influence upon milk production}

Retention of a f t e r birt h. During the entire period of investigation, retention of afterbirth occurred 96 times, or $10.8 \%$ of the total calvings. No changes 
in the relative frequency of afterbirth retention (in per cent of the total calvings) were observed $(0.50>\mathrm{P}>0.10)$. Likewise there were no observable differences between the winter and the pasture feeding periods $(0.20>\mathrm{P}>0.10)$. In heifer cows retention of afterbirth occurred relatively less frequently than in cows older than heifer cows $(\mathrm{P}<0.01)$. The frequency of afterbirth retention in heifer cows was $5.4 \%$ and in older cows $12.7 \%$ of the total calvings. Twinning is often associated with retention of afterbirth. In all these cases the duration of the dry period was at least one month.

Afterbirth retention is often repeated in the same cows. Statistical examination of cows which calved at least three times during the period of investigation showed, however, that the repeatability of this disturbance was not significant $(0.20>$ $\mathrm{P}>0.05)$.

In cases when the afterbirth is retained, the condition is treated by removing the placenta on the day following calving or on the subsequent day. The uterus is then washed with $100-200 \mathrm{ml}$ of a $331 / 3 \%$ solution of sulpha mezathine. If the uterus is bleeding, the placenta is not removed but instead Marfanil-Prontalbin rods are used.

In most cases $(70 \%)$ retention of afterbirth did not appear to have an unfavorable effect on lactation. In those $30 \%$ of the cases which showed trouble, the influence was generally mild, amounting to a decline in milk production of only $2-5 \mathrm{~kg}$ per day during the first week after calving. In only two instances was there a severe disturbance. No observable effect on the peak production was caused by retention of afterbirth. The influence of this disturbance was evident only in exceptional cases and was limited to the beginning period of lactation. In such instances the total reduction in milk production was several tens of kilograms, which is of no great significance in the total annual yield. If the retained afterbirth had been left untreated, however, it would obviously have had a serious influence on lactation (cf. p.00).

Difficult calving. Difficult calving occurred in 27 cases, or $3.1 \%$ of the total. This condition was considerably more frequent among heifer cows than among older cows $(\mathrm{P}<0.001)$. Among the former $8.9 \%$ of the calvings required assistance, whereas among the latter only $1.1 \%$ of the calvings were difficult. No difference in the frequency of this disturbance was observed between the winter and the pasture periods $(0.30>\mathrm{P}>0.20)$. The duration of the dry period was at least one month.

Difficult calving occurs when the pelvic cavity of the cow is too narrow, when the contractions are too weak, or when the position of the calf is faulty. When twins are born, assistance is usually required. No serious injuries have occurred in connection with difficult calvings.

In the greatest share of the cases of difficult calving, there was no observable influence on the subsequent milk production. In only $1 / 4$ of such cases was there a slight reduction in milk yield, amounting to $2-3 \mathrm{~kg}$ daily for about one week following calving. Even in such cows, there was evidently no influence on the lactation peak.

In four instances difficult calving was associated with the birth of twins or 
a dead calf, and in these cases lactation of the cow was severely disturbed. These instances are described in more detail later in this paper.

$\mathrm{T}$ win $\mathrm{n}$ ing. Twinning occurred in 14 calvings, or $1.6 \%$ of the total. In 8 of these cases both calves were alive at birth, in 3 cases one calf was alive and the other dead, and in 3 cases both calves were dead at birth. The combined weight of the twins averaged $60 \mathrm{~kg}$, ranging from 41 to $73 \mathrm{~kg}$. The average weight of calves in the Viik herd is $33 \mathrm{~kg}$ in those cases when one calf is born alive. The duration of gestation in instances of twinning was normal, averaging 275 days and ranging from 273 to 276 days.

Of the cases of twinning, one cow calved for the first time, three for the second time, and the remaining 10 cows for the third time or more. One cow gave birth to twins three times, and its daughter also had twins once. About one-half of the twinnings were associated with retention of afterbirth and nearly one-third with difficult calving.

The influence of twinning on lactation has been examined in those cases where both calves were alive at birth. In such instances, there was no apparent effect on the shape of the lactation curve nor on the peak milk production. Only one cow showed a slight disturbance in its lactation during about one week after calving. Those cases in which one or both of the calves were born dead are described in the following section.

$\mathrm{B}$ ir th of a dea d c a l f. When only normal gestation lengths are considered, the birth of a dead calf occurred in 18 cases, or $2.0 \%$ of the calvings. The duration of gestation averaged 279 days, ranging from 272 to 298 days. Excluding one calf, the weight of the dead calves was nearly normal. When one calf was born, the average weight was $31 \mathrm{~kg}(19-39 \mathrm{~kg})$, and when twins were born, their combined weight averaged $61 \mathrm{~kg}(55-73 \mathrm{~kg})$. The one exceptional calf weighed only $13 \mathrm{~kg}$. No significant difference in relative frequency of births of dead calves was observed between heifer cows and older cows $(0.50>\mathrm{P}>0.30)$, nor between calvings occurring in the winter and the pasture periods $(0.20>\mathrm{P}>0.10)$.

In evaluating the effect of this disturbance on lactation, the cases in which one dead calf were born have been separated from the cases of twinning. The former situation occurred in 12 instances and the latter in 6 . When only one dead calf was born, the shape of the lactation curve was affected in only two cases; in these, lactation began more slowly than normal. In five cases, however, the peak milk production was diminished, and in three of these (1/4 of the total) the disturbing influence was severe. In these three instances the lactation peak was about $5 \mathrm{~kg}$ lower and the 12-month milk production about $500 \mathrm{~kg}$ (ca. $10 \%$ ) lower than the corresponding values for these same cows in normal lactations. These cases also include the calving in which the calf weight was only $13 \mathrm{~kg}$.

The influence of this disturbance in cases of twinning could be studied only with four cows, since the remaining two were inflicted with other diseases. Two of these four cows showed a moderate disturbance, with a slightly lower milk production at the beginning of lactation than was expected. The other two cows were more severely affected, and their lactation peak was about $4 \mathrm{~kg}$ lower than expected.

The effect of this disturbance upon the total milk production during the 12- 
month lactation period was investigated for only one cow, and in this case the decrease was about $600 \mathrm{~kg}$ (ca. $16 \%$ ).

The birth of a dead calf is thus seen to have influenced lactation in quite different ways among the individual cases. In some instances it had no effect whatsoever, whereas in others it had a serious detrimental effect. On the basis of the experimental material, it is not possible to establish whether the influence was more severe in cases of twinning than when only one calf was born dead. It is conceivable that the birth of a dead calf in the final phases of gestation and the associated decrease in milk production are not directly causally related to one another, but that both of these phenomena are the result of a common disturbing factor.

A b o r t i o n. Abortion occurred in 13 cases, or $1.5 \%$ of the calvings, assuming that abortion has taken place when the duration of gestation was less than 270 days (cf. 00 p. ). The so-called early abortions are not included in these figures, since they are not followed by a new lactation period. The shortest gestation period among the cows investigated was 178 days. The cases of abortion occurring were not due to the disease contagious abortion. Only single calves were born in the instances of abortion; three of these were alive and 10 dead.

Among the cases when the calf was born alive, in one instance the gestation period was 267 days and the weight of the calf $36 \mathrm{~kg}$, in the second case the figures were 246 days and $17 \mathrm{~kg}$, and in the third case 234 days and $19 \mathrm{~kg}$. When the calf was born dead, the average duration of gestation was 227 days (range 178-267) and the average weight of the fetus $15 \mathrm{~kg}(3-31)$. Abortion occurred in both heifer cows and in older cows, and likewise it occurred both during the winter and the pasture periods.

In general, abortion caused considerable disturbance in the lactation of the cow. The experimental material does not indicate if the extent of disturbance depended upon whether the calf was alive or dead at birth. On the other hand, the important factors appear to be the number of times the cow had calved as well as the duration of gestation.

In five cases the cow calved for the fourth time or more. In four of these cases the effect of abortion on lactation could be observed. The duration of gestation averaged 254 days $(234-265)$ and the weight of the calf averaged $26 \mathrm{~kg}(19-31)$. In three instances the cow was dry for at least 40 days, while one cow was not dry at all. In these four cases the influence of abortion upon milk production was realtively slight. Lactation, however, began slowly and the peak was $3-5 \mathrm{~kg}$ lower than expected.

In four cases abortion occured when the cow calved for the second time. The duration of the gestation period averaged 216 days $(184-246)$ and the average weight of the fetus was $10 \mathrm{~kg}(3-17)$. One cow had been dry for about one month, while the other three were not dry at all. The cows in this group differed from those which had calved for the fourth time or more both in terms of their age and also in the fact that their gestation was shorter and the weight of the fetus considerably less. The influence of abortion upon milk production in these cows was severe. The lactation peak was $7-17 \mathrm{~kg}$ less and the 12 -month milk production $1000-3000$ $\mathrm{kg}$ less than expected. In the three most severe cases the decrease in milk yield 
amounted to about one-half of the expected yield for the entire lactation period. The disturbance was most mild in the cow with a gestation period of 246 days; it had been dry for one month and its living calf weighed $17 \mathrm{~kg}$. The lactation peak of this cow was only about $7 \mathrm{~kg}$ less and its 12 -month total milk yield about $1000 \mathrm{~kg}$ less than expected.

In four cows abortion occurred at their first calving, and in all four cases a dead fetus was born. The severity of the disturbance on lactation depended on the extent to which the udder had developed at the time of calving. Only one cow had a nearly normally-developed udder at parturition, and its lactation peak was only approximately $2 \mathrm{~kg}$ lower than expected. The duration of gestation of this cow was 232 days and the weight of its fetus $13 \mathrm{~kg}$. A second cow produced only $4 \mathrm{~kg}$ of milk during the first three days, after which it was slaughtered. Its gestation period was 227 days and the weight of its fetus $12 \mathrm{~kg}$. The remaining two cows had such incompletely developed udders at the time of abortion that they produced no milk at all. The duration of gestation of one cow was 236 days and the weight of its fetus $8 \mathrm{~kg}$; the corresponding figures for the second cow were 178 days and $6 \mathrm{~kg}$.

\section{The occurrence of metabolic disturbances and their influence upon milk production}

Parturient paresis. During the years $1946-59$ at the Viik Farm 41 cases of parturient paresis occurred, or $5.3 \%$ of the total calvings. The ailment was more frequent during the winter feeding period than during the pasture season $(\mathrm{P}<0.02)$. Its frequency in the indoor feeding period was $6.8 \%$ and in the pasture period $2.4 \%$ of the calvings. The duration of the dry period was at least one month, and it was not found to have any effect on the occurrence of parturient paresis. Afflicted cows were considerably heavier and fatter than the average.

Milk fever occurred only once in a heifer cow. Among the cows older than heifer cows, the disease was more common in the older than in the younger animals $(\mathrm{P}<0.001)$. At the second to the fourth calvings the frequency of this ailment was $3.9 \%$ and among older animals $14.7 \%$ of the calvings.

In three-fourths of the cases parturient paresis began on the day of calving or on the following day. In one case the cow showed symptoms on the day of calving but before parturition. In two cows the disease appeared twice after the same calving.

Milk fever occurred in cows whose milk production level was either average or higher than average; some of the highest-producing animals of the herd were also afflicted. The yield superiority of the cows which were subject to milk fever is also shown by the fact that only about $15 \%$ of such animals were removed from the herd because of poor production, whereas the figure for the entire herd was about $30 \%$.

Treatment of parturient paresis was performed by a veterinarian and consisted usually of intravenous administration of $400 \mathrm{ml}$ of $20 \%$ calcium borogluconate. In general the cows recovered rapidly, although in some cases the treatment had to be repeated. 
Since March 1955 cows in the final stage of pregnancy were given subcutaneous injections of vitamin D in the neck as a prophylactic measure against parturient paresis. Since March 1960 the injection was given in two portions, 5 million I.U. each; the first injection was made 7 days before the expected day of calving ( 9 months after being served) and the second on the expected calving day. Between the beginning of 1960 and the end of the control year 1961-62 (May 31, 1962) not a single case of parturient paresis has occurred.

In evaluating the influence of milk fever on lactation, consideration will first be made of those cases in which the disease appeard on the day of calving or on the following day. In these cases the effect of the ailment on the shape of the lactation curve and on the peak is estimated in the same manner as for parturient disturbances.

In general parturient paresis had no effect on the peak of lactation. In those cases in which the peak was lowered, the decrease was limited to only $1-3 \mathrm{~kg}$. In about one-third of the instances the influence of the ailment also on the shape of the lactation curve was quite small. In the remaining two-thirds of the cases, however, milk production was distinctly lowered during the early part of lactation. On the basis of Table 1, the average yield during the first three days was estimated to have declined an average of $8 \mathrm{~kg}$ per day (range $3-20 \mathrm{~kg}$ ). In severe cases the cow produced hardly any milk whatsoever during these days. In at least one-third of these animals the effect of the disease was visible as late as one week after calving. The reduction in milk production during the entire lactation period as a result of milk fever was less than $50 \mathrm{~kg}$ in mild cases, $50-100 \mathrm{~kg}$ in moderately severe cases, and around $200 \mathrm{~kg}$ in the two most severe cases.

Figure 1 shows the influence of parturient paresis on lactation (curve P). This curve is the average of 12 cows suffering from the disease. The animals were older

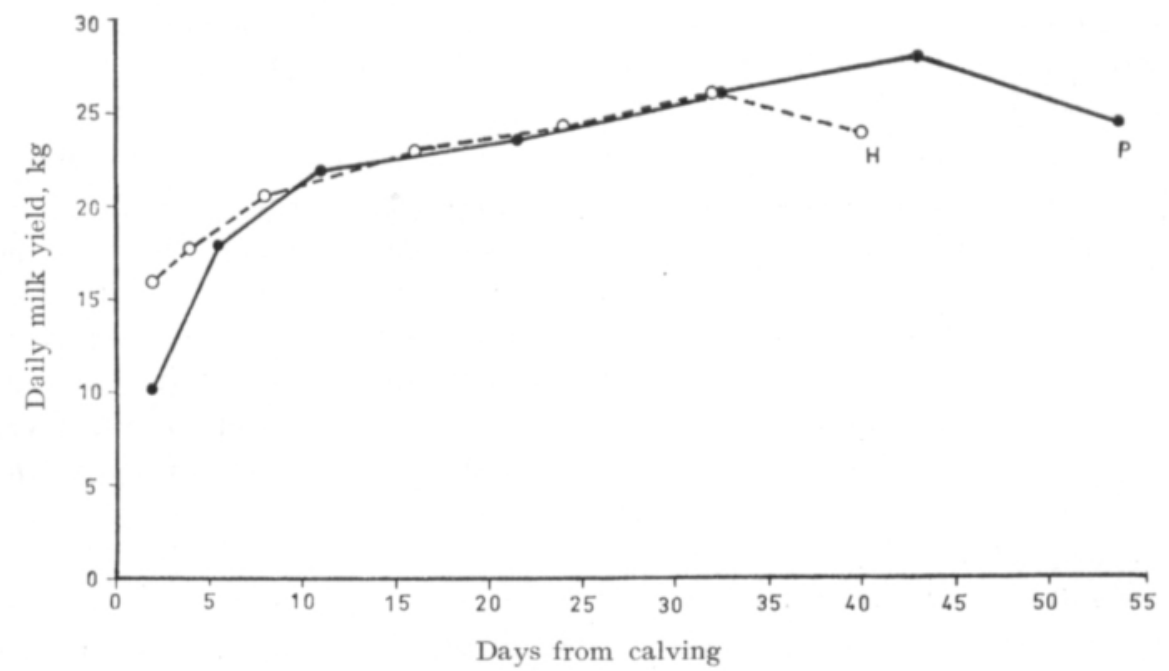

Fig. 1. The effect of parturient paresis on milk production during the ascending phase of lactation (curve $\mathrm{P}$ ). The control curve (explanation in text) is indicated by the letter $\mathrm{H}$. 
than heifer cows and they lactated during the winter feeding period. They showed symptoms of milk fever on the day of calving or on the following day and suffered from no other diseases during the lactation concerned. The control curve $(\mathrm{H})$ is the average lactation curve of cows older than heifer cows which calved in the winter feeding period of the control years $1950-51$ to $1956-57$. The depressing effect of parturient paresis on milk production at the beginning of lactation is clearly seen from this figure. The animals which were afflicted with this disease produced on the average about $2 \mathrm{~kg}$ more than the control animals; this was due to the fact that the former group consisted generally of high-producing cows. Figure 2 shows an example of the effect of parturient paresis on the lactation of an individual cow.

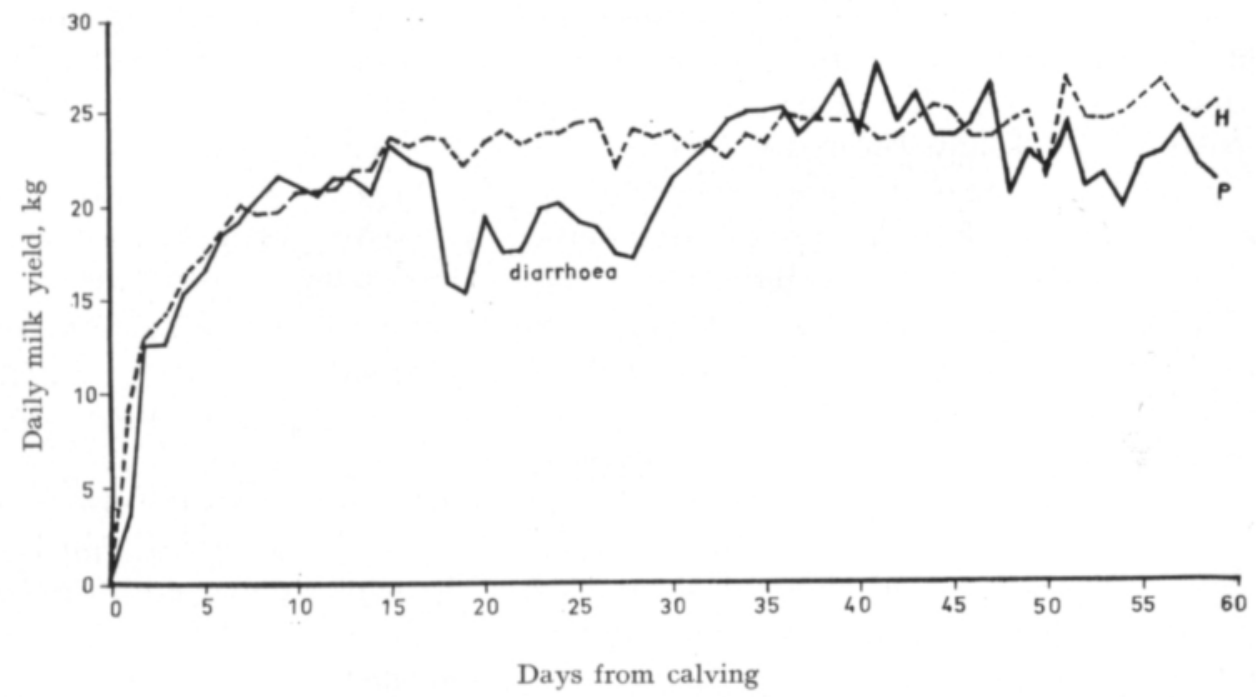

Fig. 2. The effect of parturient paresis on the milk production of the cow Elma during the ascending phase (curve P). The control curve $\mathrm{H}$ is taken from the previous lactation of this same cow.

In about one-fourth of the cases, milk fever first appeared later than on the day of calving or the following day (4 to 42 days after calving). Such cases have been evaluated by comparing the milk production during the time of the illness with the production before and after the occurrence of the illness. When the disease appeared 4 to 12 days after calving, its effect was mild. On the day when the cow became ill and on the following day its milk yield was generally $2-4 \mathrm{~kg}$ per day less than expected, and the effect of the disease usually disappeared $3-5$ days after it had started. When milk fever did not appear until 16 to 42 days after calving, its effect was more severe. On the day when the ailment appeared and on the following day the daily milk yield was $7-18 \mathrm{~kg}$ less than expected. In two cases the yield dropped to zero for a day or two. The animals recovered quickly, however, and 4-5 days after its appearance the disease was no longer evident. It is thus apparent from the above description that when parturient paresis begins later than the day following calving, the loss in milk production as a result of the disease is limited to $10-40 \mathrm{~kg}$. 
Gra s s t e t a n y. During the years $1946-59$ at the Viik Farm 33 cases of grass tetany occurred, or $4.3 \%$ of the total calvings. The incidence of the disease varied greatly in the different years. The first case occurred in 1952. The disease was most common during the years 1953, 1956 and 1957 when its frequency averaged $13.6 \%$ of the total calvings. Since the year 1959 (during the three summers 1960 62 ) not a single case of grass tetany has occurred. This is probably a consequence of the transitional phase, lasting about three weeks, during which the cows graze on pasture in the daytime but are brought to the barn at night where they were given diversified fodders. Previously there was no such transitional period, or else it lasted for only one week. In addition, magnesium mineral salts have begun to be used at the end of the indoor feeding period as well as on the pasture.

In about one-half of the cases, grass tetany appeared within the first month after calving, while in the remaining half it first appeared 2 to 8 months after calving. In more than $2 / 3$ of the cases the disease occurred during the first month on pasture and usually during the first 10 days. The remaining instances occurred during the beginning of the second month on pasture. Nearly $2 / 3$ of the cases began during the first week after the cows were left on the pasture at night.

Only one instance of grass tetany occurred in a heifer cow. Among the animals older than heifer cows the disease was more common in older than in younger cows $(\mathrm{P}<0.02)$.The frequency of the disease at the second to fourth calvings was about $4 \%$ and in older cows about $10 \%$ of the total calvings. One cow suffered from grass tetany twice during the same lactation period.

The night immediately previous to the appearance of grass tetany was often quite cold, the temperature being from -2 to $-5^{\circ} \mathrm{C}$. The disease also appeared, however, after rather mild nights $\left(+6\right.$ to $\left.+9^{\circ} \mathrm{C}\right)$. The nights previous to the outbreak of the illness were generally not rainy.

In cases of grass tetany a veterinarian was summoned. In earlier years treatment consisted of intravenous administration of $400 \mathrm{ml}$ of $20 \%$ calcium borogluconate as well as $\mathrm{P}$ and $\mathrm{Mg}$. In later years Myrilos P.M. medicine was given intravenously; this preparation consists of $20 \%$ calcium borogluconate as well as $\mathrm{P}$ (equivalent to $0.7 \%$ ) and $\mathrm{Mg}$ (equivalent to $0.3 \%$ ). Occasionally $30 \mathrm{ml}$ of Tonophosphan solution and $\mathrm{Mg}$ solution were given in addition to the calcium borogluconate.

In seven cases of grass tetany the cow died or had to be slaughtered. The daily milk production of these cows before the appearance of the disease varied from 18 to $35 \mathrm{~kg}$. In the following section consideration will be made of the effect of grass tetany on the milk production of those cows which survived the disease. Attention will primarily be paid to the cases which occurred during the first month of lactation, of which there were 13. These cases can be divided into two groups, the first (Group 1) comprising those cows which did not achieve a new peak after their illness. Such cows numbered 7 , and the outbreak of the disease occurred on the average 18 days after calving. Group 2 consisted of those cows which attained a second lactation peak after the illness. There were 6 such animals, and the outbreak of their illness occurred on the average 9 days calving.

The average lactation of Group 1 is shown by curve GT in Figure 3. The control 
curve $\mathrm{H}$ indicates the average lactation of healthy cows older than heifer cows during the pasture period in the control years $1950-51$ to $1956-57$.

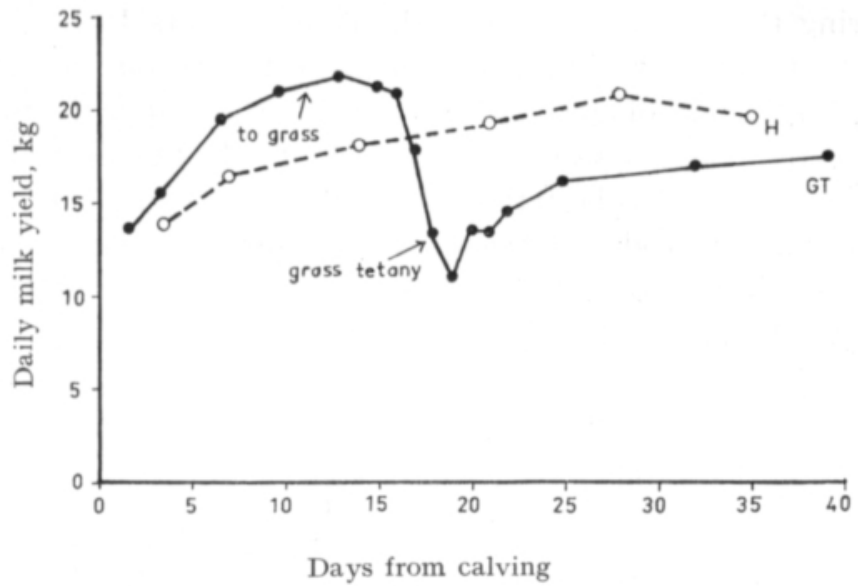

Fig. 3. The effect of grass tetany on the milk production during the ascending phase of cows in Group 1 (curve GT). The control curve (explanation in text) is indicated by the letter $\mathrm{H}$.

It can be seen from Figure 3 that the daily milk production on the day of outbreak of grass tetany and on the 4 following days averaged ca. $8 \mathrm{~kg}$ less than immediately before the disease appeared. As late as 3 weeks after the outbreak of the disease the daily milk yield was several kilograms lower than expected, thus indicating that the cows recovered quite slowly. The figure also shows that the animals which were afflicted with grass tetany produced more milk on the average before becoming ill than the animals in the control group. The former group, when healthy, yielded as much as, or more than, the average for the herd.

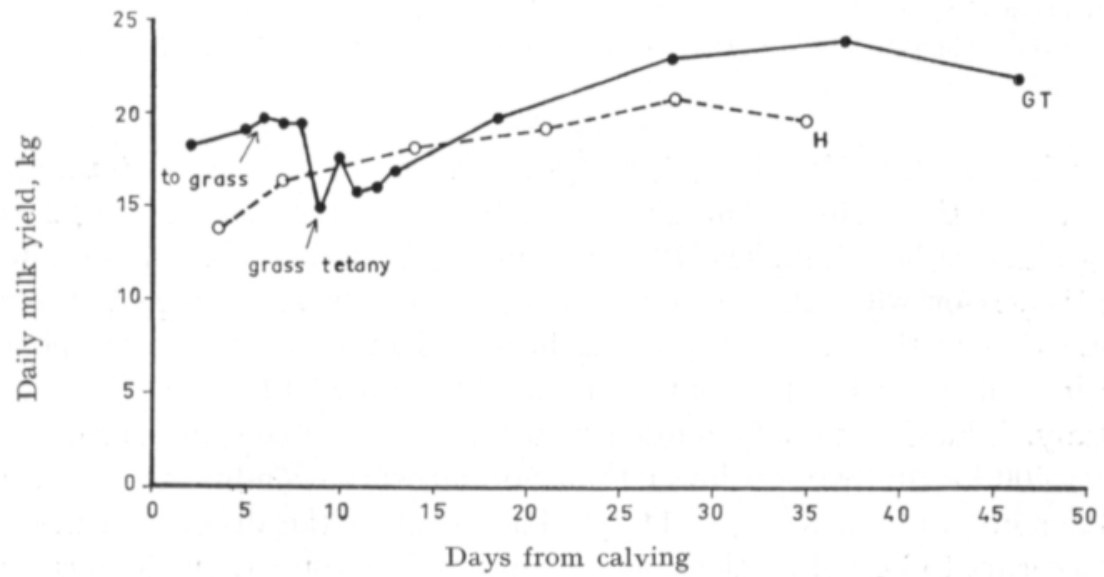

Fig. 4. The effect of grass tetany on the milk production during the ascending phase of cows in Group 2 (curve GT). The control curve (explanation in text) is indicated by the letter $\mathrm{H}$. 
In Group 2 four of the cows became afflicted with grass tetany when onefourth of the ascending phase after calving had passed. The average lactation of these cows is shown by curve GT in Figure 4. The control curve $\mathrm{H}$ is the same as in Figure 2 and denotes the average lactation of healthy animals older than heifer cows during the pasture period in the control years $1950-51$ to $1956-57$.

According to Figure 4 the influence of grass tetany on lactation appears to to be mild. The influence of grass tetany on lactation appears to be mild. The peaks of the afflicted cows, however, were lower $(2-10 \mathrm{~kg})$ than the peaks of the same animals during healthy lactations. The figure also indicates that the cows which had grass tetany produced considerably more milk before and after their illness than the cows in the control group. Figure 5 shows an example of the effect of grass tetany on the lactation of an individual cow.

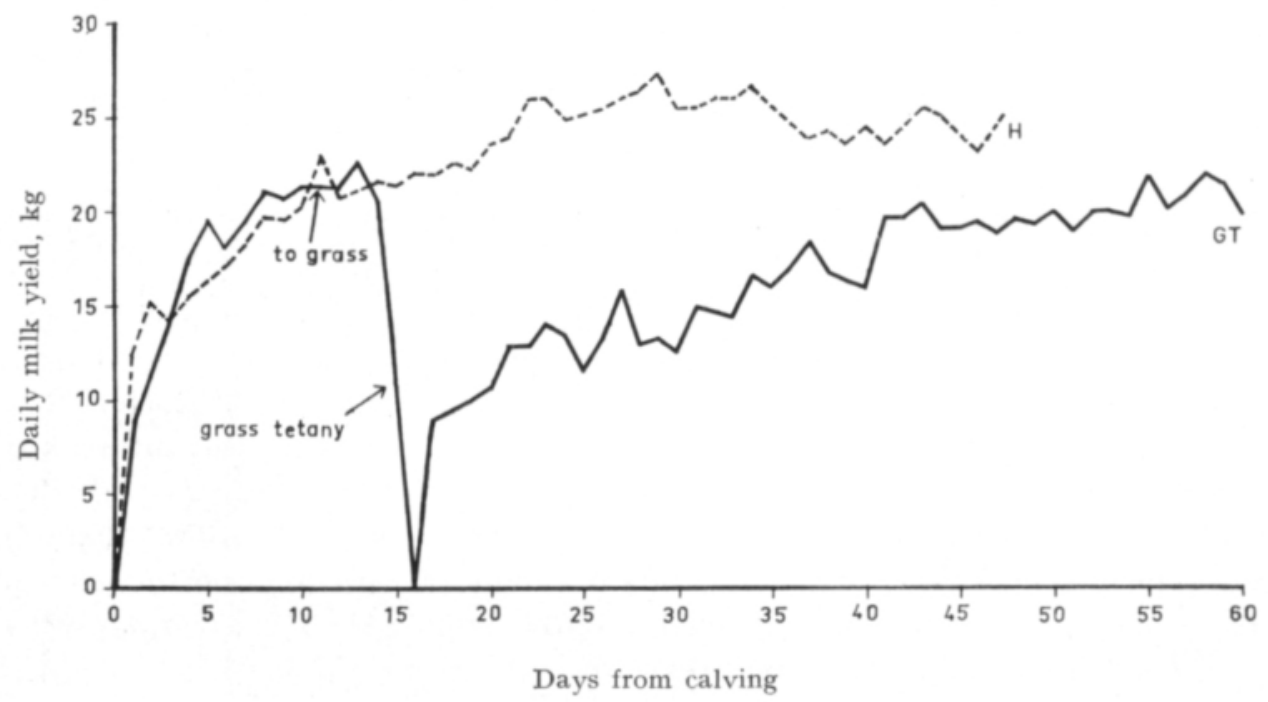

Fig. 5. The effect of grass tetany on the milk production of the cow Ipana at the beginning of lactation (curve GT). The control curve $\mathrm{H}$ is taken from the previous lactation of this same cow.

It can be seen from Figures3, 4, and 5 that the influence of grass tetany in reducing milk production extended for an appreciably longer time than during the typical ascending phase of lactation. The 12-month milk production of the 7 cows in Group 1 during the season when they were ill averaged about $900 \mathrm{~kg}$ (range $400-1500 \mathrm{~kg}$ ) lower than that of the same cows during healthy lactations. This corresponds to a decrease in milk yield for 12 months of ca. $21 \%$ (range $12-37 \%$ ) as a result of grass tetany. Likewise, the 12 -month production of the 6 cows in Group 2 was an average of $400 \mathrm{~kg}(0-800 \mathrm{~kg})$ lower than normal, corresponding to a loss in yield during 12 months of ca. $8 \%(0-14 \%)$. The effect of the disease on the cows in Group 2 appears to be milder than on the animals in Group 1. In the former group the disease appeared at the beginning of lactation, while in the latter it did not appear until around the middle of the lactation period of normal duration. 
There were 13 cases of grass tetany in which the disease did not appear until $2-8$ months after calving and in which the cows recovered. In these cases the influence of the disease on milk production was much milder than when the outbreak of the illness had occurred during the first month. On the basis of test milkings, the daily milk yield during the first month after the outbreak was generally $3-5 \mathrm{~kg}$ less than could have been expected from the yield before the disease. In some cases the effect of the illness was evident even during the second month after its appearance. The total loss in milk production as a consequence of the disease appeared to be a hundred kilograms or somewhat more, although the yield loss in one cow was estimated to be around $600 \mathrm{~kg}$. It can be mentioned that this same cow became afflicted with grass tetany again in the following summer and died on the day that the disease broke out.

K e t o s i s. During the control years 1946-47 to $1961-6230$ cases of ketosis were observed at the Viik Farm, corresponding to $3.4 \%$ of the calvings. The frequency of this disease varied greatly in the different years. It was most frequent in the years 1958 and 1959 , during which 11 cases occurred (7.6\% of the calvings). In general, ketosis was common in the spring; in the years 1957, 1958 and 1961 it also occurred in the autumn. On the basis of the need for medication, it appears that ketosis occurring in the autumn is generally more severe than cases in the spring. In relation to the number of calvings, there was no significant difference in frequency of this disease between the winter and the pasture feeding periods $(0.20>$ $\mathrm{P}>0.10$ ).

Ketosis did not occur in heifer cows. It was equally common in cows calving for the second to the fourth times as in older animals. Parturient paresis and grass tetany, on the contrary, were more prevalent among older than younger cows. The duration of the dry period did not appear in the present investigation to have any effect on the incidence of ketosis. The dry period of afflicted cows was at least one month in length, averaging 70 days. During the period of illness the animals lost an average of nearly $30 \mathrm{~kg}$ of body weight.

In 20 of the above-mentioned 30 ketosis cases the disease began in the first month after calving; in 8 cases it began in the second month and in 2 cases still later. During the interval $21-30$ days after calving nearly one-half of the cases of ketosis began. The disease was considered to have begun when the odor of acetone became evident in the milk or breath of the cows. At the same time the disease was confirmed by the urine acetone reaction using Rothera's reagent. The animal, however, often showed a lack of appetite before such visible evidence of the disease.

In severe cases of ketosis, the animals were treated by a veterinarian. Medication has often consisted of calcium borogluconate (Myrilos P.M.D. 200-600 ml) or glucose given intravenously or subcutaneously as well as $50 \mathrm{ml}$ of aminothylon (methionene) subcutaneously in the neck. Occasionally 1 gram of cortisone was administered. Oral medication consisted usually of $1 / 2$ litre of glycerol given three times, often accompanied by $1 / 2 \mathrm{~kg}$ yeast, $1 / 4^{-1} / 2 \mathrm{~kg}$ sugar and a cup of $\mathrm{Na}$ propionate, often given in several portions. In addition, rumen liquid was often given to the animals, generally in amounts of $4-6$ liters. 
In evaluating the influence of ketosis upon lactation, the cases can be divided into two groups of nearly equal size. Group 1 comprised cows which did not attain a new lactation peak after the illness, while Group 2 consisted of cows which did reach a second peak after recovering from the illness.

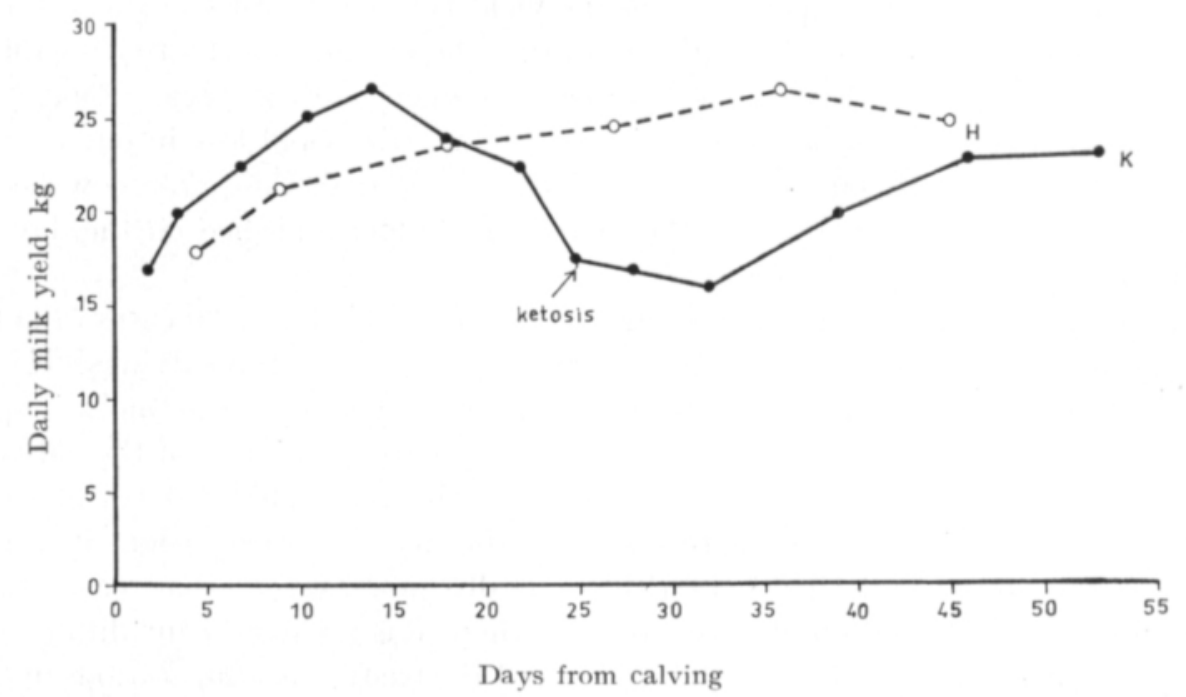

Fig. 6. The effect of ketosis on the milk production of cows in Group 1 at the beg inning of lactation (curve K). The control curve (explanation in text) is indicated by the letter $\mathrm{H}$.

The average lactation of Group 1 is shown by curve $\mathrm{K}$ in Figure 6 . In these cows the time elapsing between calving and confirmation of the disease was at most 5 weeks and averaged 25 days. The control group indicated by curve $\mathrm{H}$ consisted of healthy animals older than heifer cows during the indoor feeding period in the control years $1957-58$ to $1960-61$.

It can be seen from Figure 6 that lactation declined already a week before the presence of ketosis was established. At the time of confirmation of the disease and during the following two weeks, milk production was about $10 \mathrm{~kg}$ lower than expected. Recovery occurred slowly, and even four weeks after the disease had been established the milk yield was several kilograms less than expected. In the area shown in the figure, a loss in milk production is seen amounting to at least $200 \mathrm{~kg}$ as compared to the expected production, corresponding to a decrease of at least $3 \%$ for the whole lactation period. During the first two weeks after calving, the cows which became ill with ketosis lactated distinctly more abundantly than the control animals. The lactation peak of the afflicted cows, however, averaged ca. $3 \mathrm{~kg}$ less than that of the same cows during normal lactations. This fact seems to indicate that the cows which suffered from ketosis had a tendency to be higher producers than the herd average.

Figure 7 presents the average lactation of the cows in Group 2 beginning one week before establishment of the disease and ending 5 weeks after its establishment 


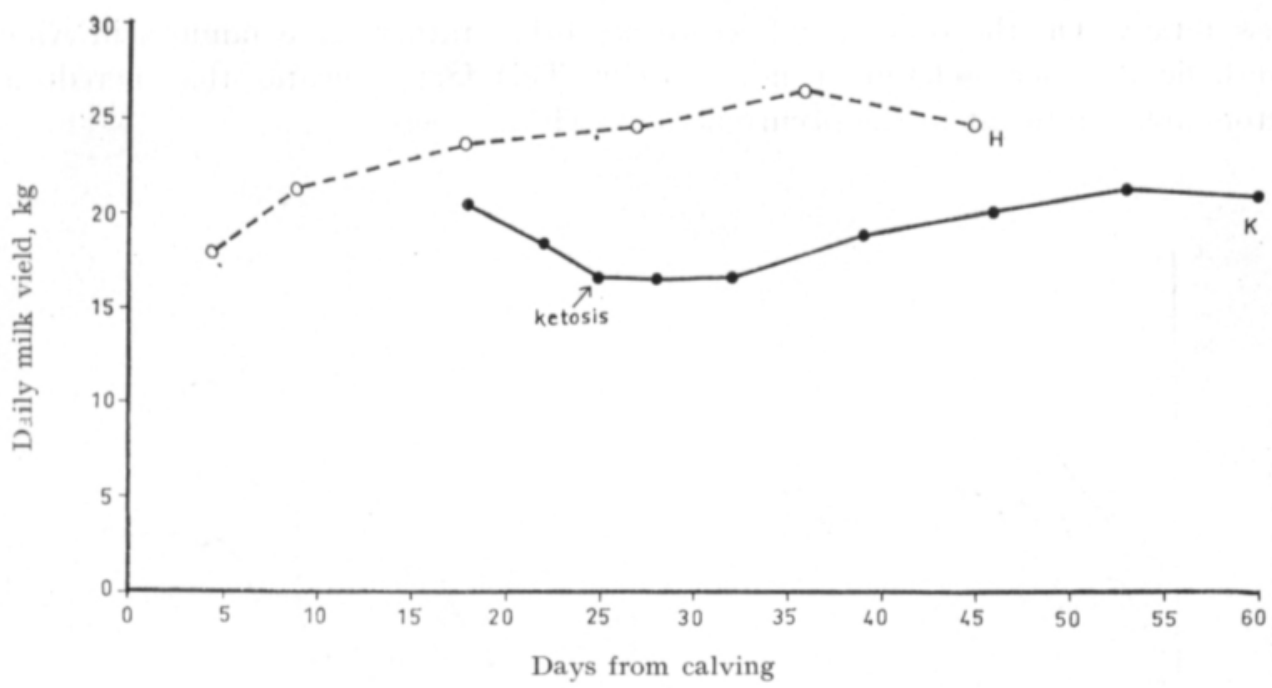

Fig. 7. The effect of ketosis on the milk production of cows in Group 2 at the beginning of lactation (curve $\mathrm{K}$ ). The control curve (explanation in text) is indicated by the letter $\mathrm{H}$.

(curve $\mathrm{K}$ ). The disease was established on the average 25 days after calving. The control curve $\mathrm{H}$ is the same as for Group 1.

According to Figure 7 the milk production during the time when ketosis was at its most severe stage showed a reduction of only about $4 \mathrm{~kg}$ per day as compared to a week before confirmation of the disease. As was mentioned above (Figure 4), ketosis may reduce milk production already a week before the disease has been established. It was further pointed out that, in comparison to normal lactations, the peak averaged $3 \mathrm{~kg}$ (range $0-6 \mathrm{~kg}$ ) lower than expected and that the duration of the lactation period increased. When both of these factors are taken into consideration, the decrease in milk production as a result of ketosis can be estimated to be approximately $200 \mathrm{~kg}$ in the area shown by the figure. Figure 8 shows an example of the effect of ketosis on the lactation of an individual cow.

It can be seen from Figures 6,7 , and 8 that the influence of ketosis on milk production extends beyond the typical ascending phase of lactation. Consequently it can be assumed that the decline in milk production for the entire lactation period is more than the above-mentioned $200 \mathrm{~kg}$. The effect of the disease on the yield of milk during 12 months could be estimated only for the cows in Group 2. The decrease in their milk production averaged around $300 \mathrm{~kg}$ (range $0-600 \mathrm{~kg}$ ), amounting to about $6 \%$ (range $0-12 \%$ ). There were three cows in this group whose lactation peak was apparently unaffected by ketosis and whose 12-month milk production appeared to be normal.

\section{The repeatability of metabolic disturbances of cows}

Among the cattle at the Viik Farm there are certain families in which metabolic disturbances commonly occur. This concerns especially parturient paresis and 
grass tetany. On the other hand, there are other rather large families in which metabolic disorders seldom or never occur. This fact indicates that hereditary factors are significant in the occurrence of such disorders.

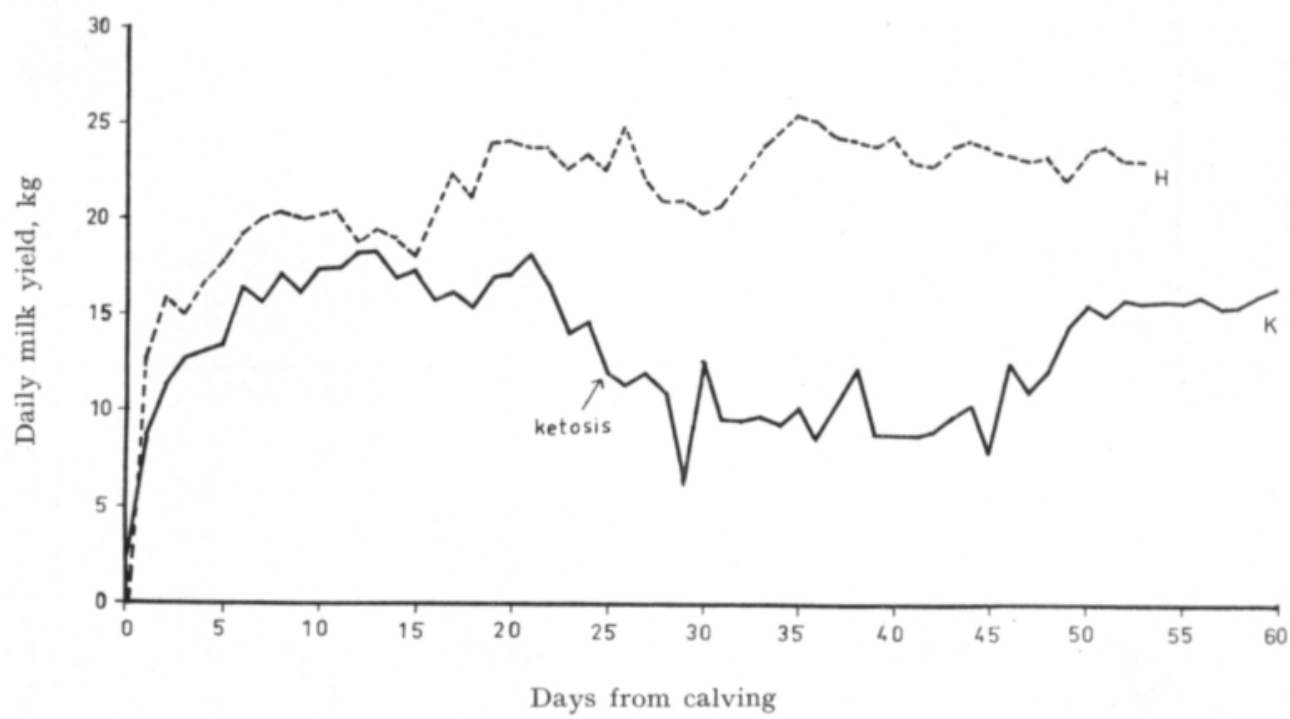

Fig. 8. The effect of ketosis on the milk production of the cow Maikki at the beginning of lactation (curve $\mathrm{K}$ ). The control curve $\mathrm{H}$ is taken from the second following lactation.

From 1947 until the end of 1959 a total of 93 cases of metabolic disturbances occurred in 56 cows. These were distributed as follows: parturient paresis 41 cases in 29 cows, grass tetany 33 cases in 23 cows, and ketosis 20 cases in 19 cows. These figures show that parturient paresis and grass tetany often occurred twice or more in the same animal. Also, both diseases sometimes occurred in the same cow. There were 11 cows in the investigation which were afficted by both parturient paresis and grass tetany. On the other hand, there were only three cows which had both ketosis and parturient paresis, and likewise only three cows in which both ketosis and grass tetany occurred. Two animals (mother and daughter) suffered from all three metabolic disorders.

Since parturient paresis and grass tetany often occur in the same animal, these two conditions were considered as one disorder in statistically examining the repeatability of these disorders in cows. For the statistical examination, data were collected on the occurrence of these disturbances in those cows which calved at least three times during the period 1947-59. Such cows numbered 129 and they had a total of 581 calvings. (Examination was performed using analysis of variance with one dimension in which the value corresponding to the occurrence of the disease $=1$ and absence of the disease $=0$ ). The result indicated that the repeatability of these metabolic disorders in the cows was quite significant $(\mathrm{P}<0.05)$. 


\section{$S u m m a r y$}

The present investigation deals with the occurrence of parturient disturbances and certain metabolic diseases in Ayrshire cows at the Viik Farm and the effect of these disorders on milk production, especially during the ascending phase of lactation. The experimental material consists of the daily milk weighings and the health data on lactating cows which have been kept on record since the year 1947 . The number of cows in the herd has been about 70, and approximately 900 calvings have occurred between 1947 and the end of the control year 1961-62. In evaluating the influence of parturient and metabolic disturbances on milk production, endeavours were made to estimate how much the disturbance changed the shape of the lactation curve at the ascending phase and decreased the peak production. In connection with some of the disturbances, the effect on the total milk production during the 12-month lactation period was also estimated. The metabolic disorders (parturient paresis, grass tetany and ketosis) were generally treated by a veterinarian. In cases of afterbirth retention and difficult calving, the herd foreman performed the necessary measures. The results found in this investigation were as follows:

Retention of afterbirth occurred in $10.8 \%$ of the calvings. It was relatively more frequent in older cows than in heifer cows. In general this disorder did not affect lactation or caused only a slight decline in milk yield at the beginning of lactation.

Difficult calving occurred in $3.1 \%$ of the calvings. It was relatively much more frequent in heifer cows than in older animals. There was generally no influence on lactation as a result of difficult calving or only a slight decline in milk production at the beginning of lactation.

Twinning occurred in $1.6 \%$ of the calvings with a normal gestation period. When the calves were alive at birth, there was no adverse effect on milk production.

The birth of a dead calf occurred in $2.0 \%$ of the calvings with a normal gestation period. Its effect on milk production varied in the individual cases. Sometimes there was no effect at all on milk yield, whereas other times there was a decrease in milk production at the beginning of lactation or a reduction in the production peak. In some cases a loss of as much as $500-600 \mathrm{~kg}(10-16 \%)$ during the $12-$ month lactation period was observed.

Abortion occurred in $1.5 \%$ of the calvings when the duration of gestation was from 178 to 267 days. The effect of abortion on lactation depended essentially on the number of times the cow had calved and on the length of gestation. When the cow calved for at least the fourth time and the gestation period was $234-265$ days, abortion had only a mild influence on milk production. When the cow aborted at its second calving and the gestation period was 184-246 days, its 12-month production was $1000-3000 \mathrm{~kg}$ less than expected. In those cases when the cow aborted at its first calving and the gestation period was 178 - 236 days, its udder was generally so undeveloped that it produced no milk.

Parturient paresis occurred in $5.3 \%$ of the calvings. It occurred commonly in high-producing animals and was more frequent in older cows than in younger 
ones; in addition, it was relatively more frequent during the winter than the pasture feeding period. The disease began most usually on the day of calving or on the following day. Subcutaneous injection of vitamin D proved to be an effective prophylactic measure against this disturbance. When parturient paresis occurred on the day of calving or the following day, it generally had a severe effect on milk production at the very beginning of the ascending phase of lactation (Fig. 1). Its effect on the peak, however, was slight or nonexistent. The reduction in the 12month milk production caused by this disease was most often $50-100 \mathrm{~kg}$. When the disease occurred at a later stage of lactation, its influence lasted only about $3-5$ days and reduced the milk production by $10-40 \mathrm{~kg}$.

Grass tetany occurred in $4.3 \%$ of the calvings. It occurred generally in highproducing animals and was more frequent in older cows than in younger ones; furthermore it usually occurred at the beginning of the pasture period, most often in cows which had recently calved. Effective preventative measures against grass tetany proved to be a long transitional period between winter feeding and pasturing as well as the use of magnesium-containing mineral salts on the pasture. In about $1 / 5$ of the cases of this disease, the animal died or had to be slaughtered. Even in those cases when the cow recovered, the disease grealty reduced the daily milk yield and its adverse effect lasted for a long time (Figs. 2 and 3). When grass tetany occured during the first month after calving, the 12-month milk production was decreased by several hundred kilograms, even as much as over $1000 \mathrm{~kg}$. On the other hand, when the disease occurred $2-8$ months after calving, the loss in milk production was generally only a hundred kilograms or somewhat more.

Ketosis occurred in $3.4 \%$ of the calvings, being prevalent generally in highproducing cows. It did not occur in heifer cows, but among the other cows it was equally frequent in the younger animals as in the older ones. The disease usually began during the first month after calving. It greatly reduced the daily milk yield and at the same time its effect lasted for a long time (Figs. 4 and 5). The average decrease in production for the 12-month lactation period was estimated at $300 \mathrm{~kg}$ $(6 \%)$, ranging from 0 to $600 \mathrm{~kg}(0-12 \%)$.

The frequent occurrence of parturient paresis and grass tetany in certain families and generally several times in the same cow indicates that hereditary factors have a singnificance on the occurrence of these diseases. In the case of ketosis, however, no such hereditary influence was observed. Since both of the former diseases often occurred in the same cow, they were considered as a single disorder in examining their repeatability in the cows. Statistical examination showed that the repeatability of parturient paresis and grass tetany among the cows in the present investigation was rather significant.

\section{REFERENCES}

(1) Axelsson, J. 1943 Nötkreaturens utfodring och skötsel. 386 p. Stockholm.

(2) Becker, M. 1961. Studien über die Grastetanie (Weidetetanie) in Deutschland. Züchtungskunde 33: $328-331$.

(3) Bonnier, G. \& Tedin, O. 1940. Biologisk variationsanalys. 325 p. Stockholm.

(4) Camenzind, T. 1944. Handbuch der Rindviehzucht und -Pflege. 583 p. Bern. 
(5) Eскцеs, C. H., Revised by Anthony, E. L. 1956. Dairy cattle and milk production. 587 p. New York.

(6) Ender, F. \& Dishington, I. W. \& Helgebostad, A. 1962. Parturient paresis and related forms of hypocalcemic disorders induced experimentally in dairy cows. Part II. Studies on the etiological importance of feeding prepartal diets high in calcium and low or normal in phosphorus in relation to development of milk fever. Effect of high and low alkalinity of diets. Acta Veter. Scand. Suppl. 1. Vol. 3. 52 p.

(7) Garner, F. H. 1948. British dairying. 263 p. London.

(8) Hibss, J. W. \& Pounden, W. D. 1955. Studies on milk fever in dairy cows. IV. Prevention by short-time, prepartum feeding of massive doses of vitamin D. J. Dairy Sci. 38: 65-72.

(9) Hulden, E. 1949. Kotieläinten lisääntyminen. Maatalouden Eläinlääkärikirja. Porvoo-Helsinki.

(10) Jönsson, G. 1960 a. On the etiology and pathogenesis of parturient paresis in dairy cows. Acta Agricult. Scand. Suppl. 8. 78 p.

(11) - 1960 b. Profylaktisk behandling av paresis puerperalis med peroral tillförsel av D-vitamin. Nord. veterinärmedicin 12:105-112.

(12) Meadows, C. E. \& Luch, J. L. 1957. Twinning in dairy cattle and its relation to production. J. Dairy Sci. 40: 1430-1436.

(13) Mizrachi, M. 1962. The use of vitamin $D_{3}$ for the prevention of milk fever. Rehuah vet. 19 (2) $82-84$; \& 108-06. Ref. Dairy Sci. Abstr. Vol. 25 No 1, Januar 1963.

(14) MÃ KELÃ, A. 1962. On designing the average lactation curve at the ascending phase. J. Sci. Agric. Soc. Finland 34: 162-168.

(15) - - 1962. The lactation curve of the cow at the ascending phase. Ibid. $34: 173-186$.

(16) - - \& Ortrila, R. 1955. Tiineysajan pituus Viikin opetus- ja koetilan ayrshirekarjassa. Summary: Duration of gestation in the Ayrshire cattle on the Viik Experimental Farm. Ibid. 27: $77-84$.

(17) Nordfeldt, S. 1944. Vitaminer och mineralämnen i husdjursskötseln. 149 p. Stockholm.

(18) Roemer \& Scheibe \& Schmidt \& Woermann 1953. Handbuch der Landwirtschaft IV. Besondere Tierzuchtlehre. 532 p. Berlin und Hamburg.

(19) Rоoк, J. A. F. \& Storry, J. E. 1962. Magnesium in the nutrition of farm animals. Nutrition Abstr. \& Rev. 32: 1055-1077 (October 1962).

(20) SaArinen, P. 1956. Lypsylehmillä runsaan tuotannon vaiheessa esiintyvistä rasitustaudeista. Maatalous 49: $8-15$ ja $28-31$.

(21) Sнaw, J. C. 1956. Ketosis in dairy cattle. A review. J. Dairy Sci. 39: 402-434.

(22) _- 1961. Metabolic disturbances associated with lactation. Milk: the Mammary Gland and Its Secretion, Vol. II, p. 89-135.

(23) VAINikaINEN, V. 1946. Eräitä näkökohtia perinnöllisten tekijäin vaikutuksesta nautakarjan hedelmällisyyteen. Summary: Some points of view regarding the effect of hereditary factors on the fecundity of cattle. J. Sci. Agric. Soc. Finland 18: 165-181.

(24) Westermarck, H. 1949. Kotieläinten sisäiset ja ulkonaiset taudit, jotka eivät ole tarttuvia. Maatalouden Eläinlääkärikirja.

\section{SELOSTUS:}

\section{POIKIMISEEN LIITTYVIEN HÄIRIÖIDEN JA AINEENVAIHDUNTATAUTIEN ESIINTY- MISESTÄ LEHMÅLLÄ JA NIIDEN VAIKUTUKSESTA MAIDONTUOTANTOON}

AARNE MĀKELĀ

\section{Kotieläintieteen laitos, Helsingin yliopisto}

Kirjoituksessa käsitellään poikimiseen liittyvien häiriöiden ja eräiden aineenvaihduntatautien esiintymistä ja vaikutusta maidontuotantoon etupäässä herumiskautena Viikin koetilan ayrshirekarjassa. Aineistona on käytetty heruvilla lehmillä suoritettuja päivittäisiä maitopunnituksia ja sairauksia koskevaa kirjanpitoa, joita on jatkettu vuodesta 1947 lähtien. Karjan lehmäluku on n. 70 ja mainitusta vuodesta lähtien on esiintynyt n. 900 poikimista tarkkailuvuoden $1961-62$ loppuun men- 
nessä. Tarkastettaessa poikimiseen liittyvien häiriöiden ja tautien vaikutusta maidontuotantoon on pyritty arvioimaan kuinka paljon häiriö on muuttanut herumiskäyrän muotoa ja missä määrin se on alentanut herumishuippua. Joidenkin häiriöiden kohdalla on myös pyritty arvioimaan häiriön vaikutus lypsykauden tuotantoon. Aineenvaihduntahäiriöitä (poikimahalvaus, laidunhalvaus ja ketosis) on hoitanut yleensä eläinlääkäri. Jälkeisten jäämisen on hoitanut ja synnytysavun antanut tilan karjamestari. Tarkastelussa todettiin mm. seuraavaa.

Jälkeisten jäämistä on esiintynyt $10.8 \%$ poikimisten lukumäärästä. Se on suhteellisesti yleisempi ensikantoisia vanhemmilla kuin ensikantoisilla lehmillä. Häiriö ei yleensä häirinnyt lehmän herumista tai lievästi alensi maidontuotantoa herumiskauden alussa.

Synnytysapua on annettu $3.1 \%$ poikimisten lukumäärästä. Sitä annettiin suhteellisesti paljoa yleisemmin ensikantoisille kuin niitä vanhemmille lehmille. Synnytysavun tarve ei yleensä haitannut lehmän herumista tai lievästi alensi maidontuotantoa herumiskauden alussa.

Kaksosvasikoita on syntynyt $1.6 \%$ poikimisten lukumäärästä, kun tiineysaika on normaali. Kaksosvasikoitten syntyminen ei vaikuttanut lehmän herumiseen, kun vasikat syntyivät elävinä.

Vasikka on synytynyt kuolleena $2.0 \%$ poikimisten lukumäärästä, kun tiineysaika on normaali. Vasikan syntyminen kuolleena on vaikuttanut maidontuotantoon yksittäistapauksissa eri tavalla. Toisinaan se ei vaikuttanut maidontuotantoon lainkaan, toisinaan alensi maidontuotantoa herumiskauden alussa ja toisinaan alensi herumishuippua. Yksittäistapauksissa voitiin havaita jopa $500-600$ kg (10-16\%) lasku 12 kuukauden lypsykauden tuotannossa.

Luomistapauksia oli $1.5 \%$ poikimisten lukumäärästä, kun tiineysaika vaihteli $178-267$ vrk. Luomisen vaikutus maidontuotantoon riippui oleellisesti poikimiskerrasta ja tiineysajan pituudesta. Kun lehmä poiki vähintään neljännen kerran ja tiineysaika vaihteli $234-265$ vrk, oli luomisen vaikutus maidontuotantoon suhteellisen lievä. Kun lehmä poiki toisen kerran ja tiineysaika vaihteli $184-246$ vrk, jäi 12 kuukauden lypsykauden tuotos $1000-3000 \mathrm{~kg}$ odotettua alhaisemmaksi. Kun lehmä poiki ensimmäisen kerran, oli sen utare yleensä kehittymätön tuottamaan maitoa, kun tiineysaika vaihteli $178-236$ vrk.

Poikimahalvausta on esiintynyt $5.3 \%$ poikimisten lukumäärästä. Se esiintyi yleensä korkeatuottoisilla lehmillä ja oli yleisempi vanhemmilla kuin nuoremmilla lehmillä sekä oli suhteellisesti yleisempi sisäruokinta- kuin laidunkautena. Tauti alkoi useimmiten poikimispäivänä tai sitä seuraavana päivänä. Nahanalainen D-vitamiini-injektio osoittautui hyväksi suojaksi poikimahalvausta vastaan. Kun tauti puhkesi poikimispäivänä tai sitä seuraavana päivänä, oli taudin vaikutus maidontuotantoon yleensä ankara herumiskauden alussa (piirrokset 1 ja 2). Herumishuippuun tauti vaikutti korkeintaan lievästi. Taudin 12 kuukauden lypsykauden tuotantoa alentava vaikutus oli useimmiten $50-100 \mathrm{~kg}$. Kun tauti puhkesi herumiskauden myöhäisemmässä vaiheessa, kesti taudin vaikutus maidontuotantoon vain $3-5$ vrk. Maidontuotannon menetys rajoittui tällöin $10-40$ kiloon.

Laidunhalvausta on esiintynyt $4.3 \%$ poikimisten lukumäärästä. Se esiintyi yleensä korkeatuottoisilla lehmillä ja oli yleisempi vanhemmilla kuin nuoremmilla lehmillä sekä esiintyi yleensä laidunkauden alussa, useimmiten hiljakkoin poikineissa lehmissä. Pitkä siirtymiskausi sisäruokinnasta laidunruokintaan sekä magnesiumia sisältävän kivennäissuolaseoksen syöttö laitumella osoittautuivat hyväksi suojaksi laidunhalvausta vastaan. Noin 1/5 sairaustapauksista lehmä kuoli tai jouduttiin se sairauden johdosta teurastamaan. Silloinkin kun lehmä toipui sairaudesta, sairaus alensi voimakkaasti päivittäistä maidontuotantoa samalla kuin taudin vaikutusaika oli pitkä (piirrokset 3, 4 ja 5). Kun sairastaminen tapahtui ensimmäisenä kuukautena poikimisesta, aleni 12 kuukauden lypsykauden tuotos yleensä useita satoja kiloja, jopa yli $1000 \mathrm{~kg}$. Kun sensijaan sairastuminen tapahtui $2-8$ kuukauden kuluttua poikimisesta, maidontuotannon menetys taudin johdosta oli yleensä vain toista sataa kiloa.

Ketosista on esiintynyt $\mathbf{3 , 4} \%$ poikimisten lukumäärästä. Se esiintyi yleensä korkeatuottoisilla lehmillä. Sitä ei esiintynyt ensikantoisilla lehmillä, mutta ensikantoisia vanhemmilla lehmillä se oli yhtä yleinen nuoremmilla kuin vanhemmilla lehmillä. Sairaus alkoi useimmiten ensimmåisen kuukauden kuluessa poikimisesta. Sairaus alensi voimakkaasti päivittäistä maidontuotantoa samalla kuin taudin vaikutusaika oli pitkä (piirrokset 6, 7 ja 8). Taudin 12 kuukauden lypsykauden tuotantoa alentava vaikutus voidaan arvioida keskimäärin 300 kiloksi $(6 \%)$, vaihdellen $0-600 \mathrm{~kg}(0-12 \%)$.

Poikima- ja laidunhalvauksen esiintyminen tietyissä suvuissa ja yleisesti useampaan kertaan samassa lehmässä viittaavat perinnöllisyyden merkitykseen mainittujen tautien syntymisessä. Vastaavaa ei havaittu ketosiksen esiintymisestä. Koska poikima- ja laidunhalvaukset esiintyvăt usein samoissa lehmissä, on näitä tauteja pidetty yhtenä tautina tarkastettaessa lehmien yksilöllisyyttä niihin. Lehmien yksilöllisyys näihin tauteihin oli melko merkitsevä. 